Open Access

\title{
Editorial focus: entering into the non-coding RNA era
}

\author{
Rafal Bartoszewski ${ }^{1 *}$ and Aleksander F. Sikorski ${ }^{2^{*}}$
}

\author{
*Correspondence: rafalbar@gumed. \\ edu.pl; \\ aleksander.sikorski@uwr.edu.pl \\ ${ }^{1}$ Department of Biology and \\ Pharmaceutical Botany, Medical \\ University of Gdansk, Gdansk, \\ Poland \\ ${ }^{2}$ Department of Cytobiochemistry, \\ Faculty of Biotechnology, University \\ of Wroclaw, Wroclaw, Poland
}

\begin{abstract}
Recent developments in high-throughput genotyping technologies have revealed the existence of several new classes of RNA that do not encode proteins but serve other cellular roles. To date, these non-coding RNAs (ncRNAs) have been shown to modulate both gene expression and genome remodeling, thus contributing to the control of both normal and disease-related cellular processes. The attraction of this research topic can be seen in the increasing number of submissions on ncRNAs to molecular biology journals, including Cellular Molecular Biology Letters (CMBL). As researchers attempt to deepen the understanding of the role of ncRNAs in cell biology, it is worth discussing the broader importance of this research.
\end{abstract}

Keywords: ncRNAs, microRNAs, IncRNAs, Regulation of gene expression

The correlation between genotype and phenotype has become the Holy Grail of biomedical research in recent decades. High-throughput genotyping technologies such as deep sequencing have dramatically enhanced our understanding of the function and complex organization of the eukaryotic genome. They have also revealed the existence of several new classes of RNA that do not encode proteins, instead serving other cellular roles: the non-coding RNAs (ncRNAs) [1-4].

To date, ncRNAs have been assigned a variety of functions, including regulation of gene expression, both transcriptional (eRNAs) and post-transcriptional (microRNAs; miRNAs); modulation of RNA processing (ribozymes); translation (miRNAs); and protection from foreign nucleic acids (piRNA) [1-6]. Furthermore, ncRNAs can guide DNA synthesis or genome rearrangement. Looking at these functions from a high level, we can state that these ncRNAs modulate both gene expression and genome remodeling [1]. Although some classes of ncRNA simply utilize their RNA structure to serve their biological function (ribozymes and riboswitches), the majority require specific associations with proteins (snRNPs, snoRNPs, microRNAs, piRNA and long ncRNAs) to fulfill their biological activity $[1,6,7]$.

The significant growth in number of reports on ncRNAs began in the early 2000s, when miRNAs, a class of short ncRNAs (22-25 nt), were accepted as post-transcriptional regulators of eukaryotic gene expression. The level of interest in these nucleic acids has certainly not abated. Recently, the editors of Cellular Molecular Biology Letters $(C M B L)$ have witnessed a sharp increase in the number of submissions aiming to deepen the understanding of the role of ncRNAs in cell biology. In the light of this increased attention, we would like to briefly discuss that role here.

(c) The Author(s). 2018 Open Access This article is distributed under the terms of the Creative Commons Attribution 4.0 International License (http://creativecommons.org/licenses/by/4.0/), which permits unrestricted use, distribution, and reproduction in any medium, provided you give appropriate credit to the original author(s) and the source, provide a link to the Creative Commons license, and indicate if changes were made. The Creative Commons Public Domain Dedication waiver (http://creativecommons.org/ publicdomain/zero/1.0/) applies to the data made available in this article, unless otherwise stated. 
Without doubt, miRNAs constitute the most extensively studied class of ncRNAs. Discovered in the laboratory of Dr. Victor Ambros and Dr. Gary Ruvkun in 1993, the original studied organism was Caenorhabditis elegans [8-10]. MiRNAs are now known to be present in most eukaryotes, including humans [11-13]. It is estimated that they account for $1-5 \%$ of the human genome (from $<1$ to 50,000 molecules per cell [14]) and regulate at least $30 \%$ of the protein-coding genes [15-17].

In mammalian cells, miRNAs recognize specific target mRNA sequences (with sites most frequently localized within the 3'-UTR) and initiate translational repression followed by decay of the mRNA [18-21]. However, since miRNAs rarely repress their target genes by more than $30 \%$, recent reports suggest that their function is rather to modulate gene expression then to serve as strong post-transcriptional repressors [22]. Nevertheless, some miRNAs cause large-scale switch-like effects under stress or disease conditions [23-26]. Notably, mammalian miRNAs are also active in the nucleus, where they are proposed to mediate chromatin silencing at specific loci by base pairing to nascent transcripts [27-29].

Since mammalian miRNAs are not perfectly complementary to their target mRNA sequences, specific miRNAs can modulate transcriptional networks comprising numerous interdependent targets such as like transcription factors [30]. This means that a single miRNA generally modulates multiple mRNAs and that most mRNAs are modulated by multiple miRNAs [31, 32]. This makes it extremely challenging to decipher the precise molecular mechanisms underlying the biological function of any given miRNA.

Nevertheless, it is now evident that miRNAs play a crucial role in the regulation of gene expression, controlling diverse cellular and metabolic pathways [33-35]. Importantly, miRNAs contribute to the control of developmental differentiation [30, 36-41] and disease processes [42-50]. Compelling reports studies have demonstrated that the expression profiles of certain miRNAs, the so-called oncomiRs, are deregulated in human cancer, and that these ncRNAs have either oncogenic or tumor suppressor functions [51-57]. OncomiRs have been reported to affect cancer cell proliferation and signaling, prevent cell death, stimulate invasion and metastasis, and promote angiogenesis [52, 58-66]. Obviously, understanding the mechanism governing oncomiR cellular function could provide a basis for novel anticancer strategies.

Although oncology is a major source of reports on miRNAs, they are also recognized as important mediators of cellular responses to various stress stimuli, including the hypoxia that accompanies not only cancer but also cardiovascular disorders. This cellular insult modulates miRNA expression to restore oxygen homeostasis and survive hypoxic stress [67-70]. Recent reports have provided compelling evidence that miRNAs modulate hypoxic transcriptional networks, related angiogenesis and endothelial function [39, 53, 71-79]. Furthermore, many hypoxamiRs recently described in normal endothelium were previously reported as oncomiRs, suggesting that understanding hypoxia-related changes in miRNA profiles could be beneficial for both cardiovascular and cancer research [68, 69, 80-89].

Despite miRNAs being the most often examined class of ncRNAs, the biological role of long non-coding RNA (lncRNAs; > $200 \mathrm{nt}$ ) has become recently a popular but often controversial topic [90, 91]. To date, lncRNA have been implicated in a range of developmental processes, cellular stress responses and human diseases, including cancer [92-94]. They have been proposed to carry out a large number of biological functions 
and to modulate gene expression transcriptionally and post-transcriptionally through a variety of mechanisms that include: dueling polymerase activity [95-98], antisense RNA base pairing [99, 100], inhibiting histone acetyltransferase activity and repressing transcription [101, 102], recruiting transcriptional regulators [103-106], and chromatin remodeling [102]. Despite the ongoing increase in the number of reports describing lncRNA functions, our knowledge of the mechanisms by which they act remains limited. Novel and dedicated experimental methods to explore their mechanisms of action are needed [107].

There is no doubt that understanding the role and function of ncRNAs is crucial for the further development of cell biology and that it also may contribute novel therapeutic strategies for human pathologies [108]. However, achieving this challenging goal requires further experimental research. Unfortunately, a plethora of often contradictory reports of ncRNA roles exists, especially in the context of human diseases, with the majority utilizing computational and predictive methods, lacking any experimental verification and ignoring the necessity of the mechanistic approach.

Our goals with $C M B L$ remain to reflect new and evolving advances in cellular and molecular biology, and to establish a record of accepting only reports of high-quality, innovative and state-of-the-art studies. Thus, we recommend that submitting authors consider two main criteria for reporting on ncRNA function: (i) functional experimental validation of the ncRNA related to its direct target or affected process; and (ii) mechanistic testing of the mechanism by which the ncRNA contributes to a disease or modulates cellular processes.

Notably, the means of engagement between miRNAs and their target mRNAs remains not fully understood. Even a single nucleotide change in either the miRNA or mRNA target sequence may have functional consequences [109-112]. That means that even sites strongly predicted as targets require functional validation.

Furthermore, while miRNA expression profiles often undergo dynamic changes due to epigenetic factors [113], the commonly used methods to confirm differential miRNA:mRNA binding, such as in vitro luciferase reporter assays and miRNA overexpression [114], often ignore the physiological miRNA levels in vivo. Importantly, changes in a particular gene's mRNA level are not always definitively reflected in the protein levels [115]. Studies of ncRNA-affected targets should always be accompanied by monitoring of the protein levels.

Finally, ncRNAs can directly and simultaneously modulate multiple targets - and as with transcription factors, that means their signal can transfer onto a vast number of indirect effectors. A single miRNA is usually predicted to modulate hundreds of mRNAs and thus may have multiple effects on cellular metabolism. Therefore, predictions of the cellular function of ncRNAs require verification if the ncRNA effects are direct.

Recently, guidelines were proposed for the functional annotation of miRNAs using the Gene Ontology classification [116]. Similar recommendations will hopefully soon be available for other ncRNA classes. The nomenclature for ncRNAs has not kept up with developments in the field, which often contributes to disparities in ncRNA functional assignments. Moreover, the nomenclature requires redefining to provide clear discrimination between putative and bona fide ncRNAs and to include: isomiRNAs (variants of mature miRNAs), and organellar miRNA (like mitochondria specific mitomiRNAs) [117]. Although these limitations can be challenging to address experimentally, they should be 
carefully considered when proposing a biological function for ncRNAs or connecting them with a disease phenotype.

We trust that $C M B L$ will further provide a environment to integrate novel, high-quality findings regarding the role of ncRNA in cell biology and human disease. We are inviting researchers to submit manuscripts on these topics fulfilling the above-mentioned criteria in the belief that our journal provides a professional forum to exchange knowledge and experience concerning ncRNA function in controlling cellular processes.

\section{Abbreviations}

CMBL: Cellular Molecular Biology Letters; IncRNA: long non-coding RNA; miRNA: micro RNA; ncRNA: non-coding RNA

Author contributions

Both authors wrote, read and revised the final version of the manuscript. Both authors read and approved the final manuscript.

\section{Authors' information}

Rafał Bartoszewski is a Professor in the Department of Biology and Pharmaceutical Botany, Medical University of Gdansk, Gdansk, Poland and an Editorial Board Member of Cellular and Molecular Biology Letters.

Aleksander F. Sikorski is a Professor in the Faculty of Biotechnology, University of Wrocław and the Editor-in-Chief of Cellular and Molecular Biology Letters.

\section{Ethics approval and consent to participate}

not applicable.

\section{Consent for publication}

not applicable.

\section{Competing interests}

The authors declare that they have no competing interests.

\section{Publisher's Note}

Springer Nature remains neutral with regard to jurisdictional claims in published maps and institutional affiliations.

Received: 6 July 2018 Accepted: 12 September 2018

Published online: 18 September 2018

\section{References}

1. Cech TR, Steitz JA. The noncoding RNA revolution-trashing old rules to forge new ones. Cell. 2014;157(1):77-94.

2. Erhard F, Zimmer R. Classification of ncRNAs using position and size information in deep sequencing data. Bioinformatics. 2010;26(18):i426-32.

3. Szell M, Bata-Csorgo Z, Kemeny L. The enigmatic world of mRNA-like ncRNAs: their role in human evolution and in human diseases. Semin Cancer Biol. 2008;18(2):141-8.

4. Huang R, Jaritz M, Guenzl P, Vlatkovic I, Sommer A, Tamir IM, Marks H, Klampfl T, Kralovics R, Stunnenberg HG, et al. An RNA-Seq strategy to detect the complete coding and non-coding transcriptome including full-length imprinted macro ncRNAs. PLoS One. 2011;6(11):e27288.

5. Saberi F, Kamali M, Najafi A, Yazdanparast A, Moghaddam MM. Natural antisense RNAs as mRNA regulatory elements in bacteria: a review on function and applications. Cell Mol Biol Lett. 2016;21:6.

6. Ishizu H, Siomi H, Siomi MC. Biology of PIWl-interacting RNAs: new insights into biogenesis and function inside and outside of germlines. Genes Dev. 2012;26(21):2361-73.

7. Sivagurunathan S, Arunachalam JP, Chidambaram S. PIWI-like protein, HIWI2 is aberrantly expressed in retinoblastoma cells and affects cell-cycle potentially through OTX2. Cell Mol Biol Lett. 2017;22:17.

8. Lee RC, Feinbaum RL, Ambros V. The C. elegans heterochronic gene lin-4 encodes small RNAs with antisense complementarity to lin-14. Cell. 1993;75(5):843-54.

9. Lee RC, Ambros V. An extensive class of small RNAs in Caenorhabditis elegans. Science. 2001;294(5543):862-4.

10. Wightman B, Ha I, Ruvkun G. Posttranscriptional regulation of the heterochronic gene lin-14 by lin-4 mediates temporal pattern formation in C. elegans. Cell. 1993;75(5):855-62.

11. Pasquinelli AE, Reinhart BJ, Slack F, Martindale MQ, Kuroda MI, Maller B, Hayward DC, Ball EE, Degnan B, Muller P, et al. Conservation of the sequence and temporal expression of let-7 heterochronic regulatory RNA. Nature. 2000;408(6808):86-9.

12. Lagos-Quintana M, Rauhut R, Lendeckel W, Tuschl T. Identification of novel genes coding for small expressed RNAs. Science. 2001;294(5543):853-8.

13. Lau NC, Lim LP, Weinstein EG, Bartel DP. An abundant class of tiny RNAs with probable regulatory roles in Caenorhabditis elegans. Science. 2001;294(5543):858-62.

14. Ameres SL, Zamore PD. Diversifying microRNA sequence and function. Nat Rev Mol Cell Biol. 2013;14(8):475-88.

15. Rajewsky N. microRNA target predictions in animals. Nature genetics. 2006;38(Suppl):S8-13.

16. Berezikov E, Guryev V, van de Belt J, Wienholds E, Plasterk RH, Cuppen E: Phylogenetic shadowing and computational identification of human microRNA genes. Cell 2005, 120(1):21-24.

17. Rajewsky N. L(ou)sy miRNA targets? Nat Struct Mol Biol. 2006;13(9):754-5.

18. Bartel DP. MicroRNAs: target recognition and regulatory functions. Cell. 2009;136(2):215-33. 
19. Bazzini AA, Lee MT, Giraldez AJ. Ribosome profiling shows that miR-430 reduces translation before causing mRNA decay in zebrafish. Science. 2012;336(6078):233-7.

20. Bethune J, Artus-Revel CG, Filipowicz W. Kinetic analysis reveals successive steps leading to miRNA-mediated silencing in mammalian cells. EMBO Rep. 2012;13(8):716-23.

21. Djuranovic S, Nahvi A, Green R. miRNA-mediated gene silencing by translational repression followed by mRNA deadenylation and decay. Science. 2012;336(6078):237-40.

22. Ma F, Lin P, Chen Q, Lu X, Zhang YE, Wu Cl. Direct measurement of pervasive weak repression by microRNAs and their role at the network level. BMC Genomics. 2018;19(1):362.

23. Olejniczak M, Kotowska-Zimmer A, Krzyzosiak W. Stress-induced changes in miRNA biogenesis and functioning. Cellular and molecular life sciences: CMLS. 2018;75(2):177-91.

24. van Rooij E, Sutherland LB, Qi X, Richardson JA, Hill J, Olson EN: Control of stress-dependent cardiac growth and gene expression by a microRNA. Science 2007, 316(5824):575-579.

25. Leung AK, Sharp PA. MicroRNA functions in stress responses. Mol Cell. 2010;40(2):205-15

26. Mendell JT, Olson EN. MicroRNAs in stress signaling and human disease. Cell. 2012;148(6):1172-87.

27. Benhamed M, Herbig U, Ye T, Dejean A, Bischof $O$. Senescence is an endogenous trigger for microRNA-directed transcriptional gene silencing in human cells. Nat Cell Biol. 2012;14(3):266-75.

28. Hwang HW, Wentzel EA, Mendell JT. A hexanucleotide element directs microRNA nuclear import. Science. 2007; 315(5808):97-100.

29. Catalanotto C, Cogoni C, Zardo G. MicroRNA in Control of Gene Expression: An Overview of Nuclear Functions. Int J Mol Sci. 2016;17(10).

30. Gurtan AM, Sharp PA. The role of miRNAs in regulating gene expression networks. J Mol Biol. 2013:425(19):3582-600.

31. Xu H, Zhang Y, Xie SJ, Xu SJ, Zhou H, Qu LH. Argonaute HITS-CLIP decodes microRNA-mRNA interaction maps during heart development. Cardiology. 2013;126:62-2.

32. Chi SW, Zang JB, Mele A, Darnell RB. Argonaute HITS-CLIP decodes microRNA-mRNA interaction maps. Nature. 2009; 460(7254):479-86.

33. Esau C, Davis S, Murray SF, Yu XX, Pandey SK, Pear M, Watts L, Booten SL, Graham M, McKay R, et al. miR-122 regulation of lipid metabolism revealed by in vivo antisense targeting. Cell Metab. 2006;3(2):87-98.

34. Bartel DP. MicroRNAs: genomics, biogenesis, mechanism, and function. Cell. 2004;116(2):281-97.

35. Cai $Y, Y u$ X, Hu S, Yu J. A brief review on the mechanisms of miRNA regulation. Genomics Proteomics Bioinformatics. 2009;7(4):147-54.

36. Listowski MA, Heger E, Boguslawska DM, Machnicka B, Kuliczkowski K, Leluk J, Sikorski AF. microRNAs: fine tuning of erythropoiesis. Cell Mol Biol Lett. 2013;18(1):34-46.

37. Zhang WW, Sun XF, Tong HL, Wang YH, Li SF, Yan YQ, Li GP. Effect of differentiation on microRNA expression in bovine skeletal muscle satellite cells by deep sequencing. Cell Mol Biol Lett. 2016;21:8.

38. Alvarez-Garcia I, Miska EA. MicroRNA functions in animal development and human disease. Development. 2005;132(21): 4653-62.

39. Wang $X$, Jin H, Jiang S, Xu Y. MicroRNA-495 inhibits the high glucose-induced inflammation, differentiation and extracellular matrix accumulation of cardiac fibroblasts through downregulation of NOD1. Cell Mol Biol Lett. 2018;23:23.

40. Wang Y, Zou X, Guo Y, Wang L, Liu Y, Zeng Q, Zhang X. Mechanical strain affects some Microrna profiles in pre-Oeteoblasts. Cell Mol Biol Lett. 2015;20(4):586-96.

41. Richardson BC, Patel DR. Epigenetics in 2013. DNA methylation and miRNA: key roles in systemic autoimmunity. Nat Rev Rheumatol. 2014;10(2):72-4.

42. Hayes J, Peruzzi PP, Lawler S. MicroRNAs in cancer: biomarkers, functions and therapy. Trends Mol Med. 2014;20(8):460-9.

43. Ardekani AM, Naeini MM. The role of MicroRNAs in human diseases. Avicenna J Med Biotechnol. 2010;2(4):161-79.

44. Li Y, Kowdley KV. MicroRNAs in common human diseases. Genomics Proteomics Bioinformatics. 2012;10(5):246-53.

45. Das J, Podder S, Ghosh TC. Insights into the miRNA regulations in human disease genes. BMC Genomics. 2014;15(1):1010.

46. Yang H, Wu D, Li H, Chen N, Shang Y. Downregulation of microRNA-448 inhibits IL-1 beta-induced cartilage degradation in human chondrocytes via upregulation of matrilin-3. Cell Mol Biol Lett. 2018;23:7.

47. Chen Q, Li L, Tu Y, Zheng LL, Liu W, Zuo XY, He YM, Zhang SY, Zhu W, Cao JP, et al. MiR-34a regulates apoptosis in liver cells by targeting the KLF4 gene. Cell Mol Biol Lett. 2014;19(1):52-64.

48. Vucicevic D, Schrewe H, Orom UA. Molecular mechanisms of long ncRNAs in neurological disorders. Front Genet. 2014;5:48.

49. Wang W, Kwon EJ, Tsai LH. MicroRNAs in learning, memory, and neurological diseases. Learn Mem. 2012;19(9):359-68.

50. Luck ME, Muljo SA, Collins CB. Prospects for therapeutic targeting of MicroRNAs in human immunological diseases. J Immunol. 2015;194(11):5047-52.

51. Peng Y, Croce CM. The role of MicroRNAs in human cancer. Signal Transduct Target Ther. 2016;1:15004

52. Esquela-Kerscher A, Slack FJ. Oncomirs - microRNAs with a role in cancer. Nat Rev Cancer. 2006;6(4):259-69.

53. Sun J, Yan J, Yuan X, Yang R, Dan T, Wang X, Kong G, Gao S. A computationally constructed ceRNA interaction network based on a comparison of the SHEE and SHEEC cell lines. Cell Mol Biol Lett. 2016;21:21.

54. Patel M, Antala B, Shrivastava N. In silico screening of alleged miRNAs associated with cell competition: an emerging cellular event in cancer. Cell Mol Biol Lett. 2015;20(5):798-815.

55. Fomeshi MR, Ebrahimi M, Mowla SJ, Khosravani P, Firouzi J, Khayatzadeh H. Evaluation of the expressions pattern of miR-10b, 21, 200c, 373 and 520c to find the correlation between epithelial-to-mesenchymal transition and melanoma stem cell potential in isolated cancer stem cells. Cell Mol Biol Lett. 2015;20(3):448-65.

56. Liu Y, Wang J. Therapeutic potentials of noncoding RNAs: targeted delivery of ncRNAs in Cancer cells. Adv Exp Med Biol. 2016;927:429-58.

57. de Almeida RA, Fraczek MG, Parker S, Delneri D, O'Keefe RT: Non-coding RNAs and disease: the classical ncRNAs make a comeback. Biochem Soc Trans 2016, 44(4):1073-1078.

58. Gong R, Lv X, Liu F. MiRNA-17 encoded by the miR-17-92 cluster increases the potential for steatosis in hepatoma cells by targeting CYP7A1. Cell Mol Biol Lett. 2018;23:16.

59. Kong R, Ma Y, Feng J, Li S, Zhang W, Jiang J, Zhang J, Qiao Z, Yang X, Zhou B. The crucial role of miR-126 on suppressing progression of esophageal cancer by targeting VEGF-A. Cell Mol Biol Lett. 2016;21:3. 
60. Viallard C, Larrivee B. Tumor angiogenesis and vascular normalization: alternative therapeutic targets. Angiogenesis. 2017;20(4):409-26.

61. van Beijnum JR, Giovannetti E, Poel D, Nowak-Sliwinska P, Griffioen AW: miRNAs: micro-managers of anticancer combination therapies. Angiogenesis 2017, 20(2):269-285.

62. Arabzadeh S, Hossein G, Salehi-Dulabi Z, Zarnani AH. WNT5A-ROR2 is induced by inflammatory mediators and is involved in the migration of human ovarian cancer cell line SKOV-3. Cell Mol Biol Lett. 2016;21:9.

63. Wang H, Wu Q, Zhang Y, Zhang HN, Wang YB, Wang W. TGF-beta1-induced epithelial-mesenchymal transition in lung cancer cells involves upregulation of miR-9 and downregulation of its target, E-cadherin. Cell Mol Biol Lett. 2017;22:22.

64. Zeng M, Zhu L, Li L, Kang C. miR-378 suppresses the proliferation, migration and invasion of colon cancer cells by inhibiting SDAD1. Cell Mol Biol Lett. 2017;22:12.

65. Liu H, Zhang N, Tian D. MiR-30b is involved in methylglyoxal-induced epithelial-mesenchymal transition of peritoneal mesothelial cells in rats. Cell Mol Biol Lett. 2014;19(2):315-29.

66. Nicolas FE. Role of ncRNAs in development, diagnosis and treatment of human Cancer. Recent patents on anti-cancer drug discovery. 2017;12(2):128-35.

67. Ivan M, Harris AL, Martelli F, Kulshreshtha R. Hypoxia response and microRNAs: no longer two separate worlds. J Cell Mol Med. 2008;12(5A):1426-31.

68. Ali N, Mah N, McLoughlin P, Costello CM. Identification of a hypoxia-responsive MicroRNA signature in lung endothelial cells. Irish J Med Sci. 2012;181:S414-4.

69. Kulshreshtha R, Ferracin M, Wojcik SE, Garzon R, Alder H, Agosto-Perez FJ, Davuluri R, Liu CG, Croce CM, Negrini M, et al. A microRNA signature of hypoxia. Mol Cell Biol. 2007;27(5):1859-67.

70. Bandara V, Michael MZ, Gleadle JM. Hypoxia represses microRNA biogenesis proteins in breast cancer cells. BMC Cancer. 2014;14:533.

71. Janaszak-Jasiecka A, Bartoszewska S, Kochan K, Piotrowski A, Kalinowski L, Kamysz W, Ochocka RJ, Bartoszewski R, Collawn JF. miR-429 regulates the transition between hypoxia-inducible factor (HIF)1A and HIF3A expression in human endothelial cells. Sci Rep. 2016:6:22775.

72. Bartoszewska S, Kamysz W, Jakiela B, Sanak M, Kroliczewski J, Bebok Z, Bartoszewski R, Collawn JF. miR-200b downregulates CFTR during hypoxia in human lung epithelial cells. Cell Mol Biol Lett. 2017;22:23.

73. Bartoszewski R, Serocki M, Janaszak-Jasiecka A, Bartoszewska S, Kochan-Jamrozy K, Piotrowski A, Kroliczewski J, Collawn JF. miR-200b downregulates Kruppel like factor 2 (KLF2) during acute hypoxia in human endothelial cells. Eur J Cell Biol. 2017;96(8):758-66.

74. Kalinowski L, Janaszak-Jasiecka A, Siekierzycka A, Bartoszewska S, Wozniak M, Lejnowski D, Collawn JF, Bartoszewski R. Posttranscriptional and transcriptional regulation of endothelial nitric-oxide synthase during hypoxia: the role of microRNAs. Cell Mol Biol Lett. 2016;21:16.

75. Zhang Y, Zhang W, Zha C, Liu Y. Platelets activated by the anti-beta2GPI/beta2GPI complex release microRNAs to inhibit migration and tube formation of human umbilical vein endothelial cells. Cell Mol Biol Lett. 2018;23:24.

76. Hassan G, Bahjat M, Kasem I, Soukkarieh C, Aljamali M. Platelet lysate induces chondrogenic differentiation of umbilical cord-derived mesenchymal stem cells. Cell Mol Biol Lett. 2018;23:11.

77. Chamorro-Jorganes A, Araldi E, Suarez Y. MicroRNAs as pharmacological targets in endothelial cell function and dysfunction. Pharmacol Res. 2013;75:15-27.

78. Njock MS, Fish JE. Endothelial miRNAs as cellular messengers in Cardiometabolic diseases. Trends Endocrinol Metab. 2017;28(3):237-46

79. Kulshreshtha R, Davuluri RV, Calin GA, Ivan M. A microRNA component of the hypoxic response. Cell Death Differ. 2008; 15(4):667-71.

80. Crosby ME, Devlin CM, Glazer PM, Calin GA, Ivan M. Emerging roles of microRNAs in the molecular responses to hypoxia. Curr Pharm Des. 2009;15(33):3861-6.

81. Janaszak-Jasiecka A, Siekierzycka A, Bartoszewska S, Serocki M, Dobrucki LW, Collawn JF, Kalinowski L, Bartoszewski R. eNOS expression and NO release during hypoxia is inhibited by miR-200b in human endothelial cells. Angiogenesis. 2018.

82. Chen Y, Zhang L, Liu WX, Wang K. VEGF and SEMA4D have synergistic effects on the promotion of angiogenesis in epithelial ovarian cancer. Cell Mol Biol Lett. 2018;23:2.

83. Feng W, Xue T, Huang S, Shi Q, Tang C, Cui G, Yang G, Gong H, Guo H. HIF-1alpha promotes the migration and invasion of hepatocellular carcinoma cells via the IL-8-NF-kappaB axis. Cell Mol Biol Lett. 2018;23:26.

84. Liyanage KIP, Ganegoda GU. Therapeutic approaches and role of ncRNAs in cardiovascular disorders and insulin resistance. Biomed Res Int. 2017;2017:4078346.

85. Thum T. MicroRNAs in cardiovascular disease — from disease mechanisms to therapeutic approaches. Vasc Pharmacol. 2012;56(5-6):329-30.

86. Siasos G, Tousoulis D, Tourikis P, Mazaris S, Zakynthinos G, Oikonomou E, Kokkou E, Kollia C, Stefanadis C. MicroRNAs in cardiovascular therapeutics. Curr Top Med Chem. 2013;13(13):1605-18.

87. Karapetsas A, Tokamani M, Kolettas E, Sandaltzopoulos R. Editorial: novel microRNAs as putative therapeutic targets in cardiovascular diseases. Curr Vasc Pharmacol. 2015;13(5):564-5.

88. Vogel B, Katus HA, Meder B. MicroRNAs as novel biomarkers in cardiovascular medicine. Nucleic Acids as Molecular Diagnostics. 2015:11-24.

89. Papageorgiou N, Tslamandris S, Giolis A, Tousoulis D. MicroRNAs in cardiovascular disease: perspectives and reality. Cardiol Rev. 2016;24(3):110-8.

90. Kung JT, Colognori D, Lee JT. Long noncoding RNAs: past, present, and future. Genetics. 2013;193(3):651-69.

91. Fang Y, Fullwood MJ. Roles, functions, and mechanisms of long non-coding RNAs in Cancer. Genomics Proteomics Bioinformatics. 2016;14(1):42-54

92. Xu X, Ji S, Li W, Yi B, Li H, Zhang H, Ma W. LncRNA H19 promotes the differentiation of bovine skeletal muscle satellite cells by suppressing Sirt1/FoxO1. Cell Mol Biol Lett. 2017;22:10.

93. Liu J, Yang C, Gu Y, Li C, Zhang H, Zhang W, Wang X, Wu N, Zheng C. Knockdown of the IncRNA SNHG8 inhibits cell growth in Epstein-Barr virus-associated gastric carcinoma. Cell Mol Biol Lett. 2018;23:17. 
94. Heilmann K, Toth R, Bossmann C, Klimo K, Plass C, Gerhauser C. Genome-wide screen for differentially methylated long noncoding RNAs identifies Esrp2 and IncRNA Esrp2-as regulated by enhancer DNA methylation with prognostic relevance for human breast cancer. Oncogene. 2017;36(46):6446-61.

95. Martens JA, Wu PY, Winston F. Regulation of an intergenic transcript controls adjacent gene transcription in Saccharomyces cerevisiae. Genes Dev. 2005;19(22):2695-704.

96. Bumgarner SL, Dowell RD, Grisafi P, Gifford DK, Fink GR. Toggle involving cis-interfering noncoding RNAs controls variegated gene expression in yeast. Proc Natl Acad Sci U S A. 2009;106(43):18321-6.

97. Latos PA, Pauler FM, Koerner MV, Senergin HB, Hudson QJ, Stocsits RR, Allhoff W, Stricker SH, Klement RM, Warczok KE, et al. Airn transcriptional overlap, but not its IncRNA products, induces imprinted Igf2r silencing. Science. 2012; 338(6113):1469-72.

98. Nagano T, Mitchell JA, Sanz LA, Pauler FM, Ferguson-Smith AC, Feil R, Fraser P. The air noncoding RNA epigenetically silences transcription by targeting G9a to chromatin. Science. 2008;322(5908):1717-20.

99. Engreitz JM, Haines JE, Perez EM, Munson G, Chen J, Kane M, McDonel PE, Guttman M, Lander ES. Local regulation of gene expression by IncRNA promoters, transcription and splicing. Nature. 2016;539(7629):452-5.

100. Wu Z, Liu X, Liu L, Deng H, Zhang J, Xu Q, Cen B, Ji A. Regulation of IncRNA expression. Cell Mol Biol Lett. 2014;19(4): $561-75$.

101. Wang X, Arai S, Song X, Reichart D, Du K, Pascual G, Tempst P, Rosenfeld MG, Glass CK, Kurokawa R. Induced ncRNAs allosterically modify RNA-binding proteins in cis to inhibit transcription. Nature. 2008;454(7200):126-30.

102. Wang KC, Yang YW, Liu B, Sanyal A, Corces-Zimmerman R, Chen Y, Lajoie BR, Protacio A, Flynn RA, Gupta RA, et al. A long noncoding RNA maintains active chromatin to coordinate homeotic gene expression. Nature. 2011;472(7341):120-4.

103. Tsai MC, Manor O, Wan Y, Mosammaparast N, Wang JK, Lan F, Shi Y, Segal E, Chang HY. Long noncoding RNA as modular scaffold of histone modification complexes. Science. 2010;329(5992):689-93.

104. Yang L, Lin C, Jin C, Yang JC, Tanasa B, Li W, Merkurjev D, Ohgi KA, Meng D, Zhang J, et al. IncRNA-dependent mechanisms of androgen-receptor-regulated gene activation programs. Nature. 2013;500(7464):598-602.

105. Khalil AM, Guttman M, Huarte M, Garber M, Raj A, Rivea Morales D, Thomas K, Presser A, Bernstein BE, van Oudenaarden A et al: Many human large intergenic noncoding RNAs associate with chromatin-modifying complexes and affect gene expression. Proc Natl Acad Sci U S A 2009, 106(28):11667-11672.

106. Zhao J, Ohsumi TK, Kung JT, Ogawa Y, Grau DJ, Sarma K, Song JJ, Kingston RE, Borowsky M, Lee JT. Genome-wide identification of polycomb-associated RNAs by RIP-seq. Mol Cell. 2010;40(6):939-53.

107. Qin D, Xu C. Study strategies for long non-coding RNAs and their roles in regulating gene expression. Cell Mol Biol Lett. 2015;20(2):323-49.

108. Di Mauro V, Catalucci D: The importance of being ncRNAs: from bit players as "junk DNA" to rising stars on the stage of the pharmaceutical industry. Annals of translational medicine 2017, 5(6):147.

109. Sethupathy P, Collins FS. MicroRNA target site polymorphisms and human disease. Trends in genetics : TIG. 2008;24(10): 489-97.

110. Moszynska A, Gebert M, Collawn JF, Bartoszewski R. SNPs in microRNA target sites and their potential role in human disease. Open biology. 2017:7(4).

111. Kroliczewski J, Sobolewska A, Lejnowski D, Collawn JF, Bartoszewski R. microRNA single polynucleotide polymorphism influences on microRNA biogenesis and mRNA target specificity. Gene. 2018;640:66-72.

112. Bartoszewski R, Kroliczewski J, Piotrowski A, Jasiecka AJ, Bartoszewska S, Vecchio-Pagan B, Fu L, Sobolewska A, Matalon $\mathrm{S}$, Cutting GR, et al. Codon bias and the folding dynamics of the cystic fibrosis transmembrane conductance regulator. Cell Mol Biol Lett. 2016;21:23.

113. Melo SA, Esteller M. Dysregulation of microRNAs in cancer: playing with fire. FEBS Lett. 2011;585(13):2087-99.

114. Jin Y, Chen Z, Liu X, Zhou X. Evaluating the microRNA targeting sites by luciferase reporter gene assay. Methods Mol Biol. 2013;936:117-27.

115. Vogel C, Marcotte EM. Insights into the regulation of protein abundance from proteomic and transcriptomic analyses. Nat Rev Genet. 2012;13(4):227-32.

116. Huntley RP, Sitnikov D, Orlic-Milacic M, Balakrishnan R, D'Eustachio P, Gillespie ME, Howe D, Kalea AZ, Maegdefessel L, Osumi-Sutherland D, et al. Guidelines for the functional annotation of microRNAs using the gene ontology. Rna. 2016; 22(5):667-76.

117. Budak H, Bulut R, Kantar M, Alptekin B. MicroRNA nomenclature and the need for a revised naming prescription. Brief Funct Genomics. 2016;15(1):65-71.

- fast, convenient online submission

- thorough peer review by experienced researchers in your field

- rapid publication on acceptance

- support for research data, including large and complex data types

- gold Open Access which fosters wider collaboration and increased citations

- maximum visibility for your research: over 100M website views per year

At $\mathrm{BMC}$, research is always in progress.

Learn more biomedcentral.com/submissions 